\title{
Peran Sistem Pengendalian Manajemen Dalam Penerapan Strategi Relationship Marketing Azizah Konveksi di Desa Jatirunggo Kec. Pringapus
}

\author{
Afita Setyowati 1 , Viqi Miftakhul Faza2, Budi Utomos \\ IAIN Salatiga, Indonesia ${ }^{2}$
}

\author{
$\varangle$ Corresponding Author: \\ Nama Penulis: Viqi Miftakhul Faza \\ E-mail: viqifaza4@gmail.com
}

\begin{abstract}
This research is a research about how the role of management control system in implementing relationship marketing strategy in a company. Where the name of the company certainly needs a strategy to increase sales. This study aims to determine the role of management control systems in implementing a relationship marketing strategy at a convection company located in the village of Jatirunggo, Kec. Pringapus. In this study, it was found that the production process had not run optimally due to rejected or defective products. Therefore, the convection party needs control in order to anticipate the damage that occurs to the products produced later. This control can be done by supervising activities at the time of production, selecting materials with good quality and providing training to the parties concerned with the production. Then, this convection Azizah distributed pamphlets through social media and posted pamphlets in crowded places to increase sales, orders and increase incoming orders. With so many customers from out of town working with Azizah convection.
\end{abstract}

Keywords: Management Control System, Relationship Marketing Strategy, Sales

\begin{abstract}
Abstrak: Penelitian ini merupakan penelitian tentang bagaimana peran sistem pengendalian manajemen dalam menerapkan strategi relationship marketing dalam sebuah perusahaan. Dimana yang namanya perusahaan tentu membutuhkan strategi untuk meningkatkan penjualan. Penelitian ini bertujuan untuk mengetahui peran sistem pengendalian manajemen dalam menerapkan strategi relationship marketing pada perusahaan konveksi yang terletak di desa Jatirunggo Kec. Pringapus. Dalam penelitian ini ditemukan adanya proses produksi yang belum berjalan secara maksimal dikarenakan adanya produk yang reject atau cacat. Maka dari itu pihak konveksi perlu adanya pengendalian agar mengantisipasi kerusakan yang terjadi pada produk-produk yang dihasilkan nantinya. Pengendalian tersebut bisa dengan cara mengawasi kegiatan pada saat produksi, memilih bahan dengan kualitas yang bagus serta memberikan pelatihan pada pihak yang bersangkutan dengan produksi.yang diproduksi. Kemudian, Azizah konveksi ini melakukan penyebaran pamphlet melalui media sosial dan menempelkan pamphlet di tempat-tempat keramaian guna meningkatkan penjualan, pemesanan dan menambah order-an masuk. Dengan begitu banyak pelanggan dari luar kota yang bekerja sama dengan Azizah konveksi.
\end{abstract}

Kata kunci: Sistem Pengendalian Manajemen, Strategi Relationship Marketing, Penjualan 
Peran Sistem Pengendalian Manajemen Dalam Penerapan Strategi Relationship Marketing Azizah Konveksi di Desa Jatirunggo Kec. Pringapus

\section{PENDAHULUAN}

\subsection{Latar Belakang}

Perusahaan harus mampu mengendalikan dan memberikan kepuasan tersendiri dengan konsumen agar dapat menjaga hubungan baik antara perusahaan dengan konsumen. Perusahaan harus mampu membuat konsumen selalu tertarik salah satunya dengan cara menjaga produk miliknya atau mungkin harus meningkatkan kualitas sehingga konsumen akan menjadi pelanggan tetap dan tidak ada keinginan berpindah tempat. Perusahaan harus mampu mengendalikan semua sumber daya yang dapat digunakan, baik sumber daya manusia, teknologi dan alat-alat serta segala hasil yang dapat diperoleh dari perusahaan sehingga proses pencapaian tersebut dapat berjalan dengan lancar.

Berdasarkan dari latar belakang tersebut, para peneliti dapat menganalisis mengenai peran sistem pengendalian manajemen dalam penerapan strategi relationship marketing pada industri konveksi di Desa Jatirunggo Kec. Pringapus.

\subsection{Tujuan Penelitian}

a. Untuk mengetahui peran sistem pengendalian manajemen pada usaha konveksi di desa Jatirunggo Kec. Pringapus

b. Untuk mengetahui penerapan strategi relationship marketing pada usaha konveksi di desa Jatirunggo Kec. Pringapus

c. Untuk mengetahui kendala yang terjadi dan solusi untuk usaha konveksi

\subsection{Tinjauan Pustaka}

\subsubsection{Pengendalian Sistem Manajemen}

Pengendalian sistem manajemen adalah suatu rangkaian kegiatan yang terjadi pada seluruh kegiatan organisasi dan berjalan dengan secara terus-menerus dan berskala. Pengendalian sistem manajemen bukanlah suatu sistem terpisah dalam suatu organisasi, akan tetapi harus ada dan dianggap sebagai suatu bagian penting dari setiap sistem yang akan digunakan manajemen untuk pengontrol dari kegiatanya. Dari kutipan Anthony and Govindarajan dalam buku yang ditulisnya yang berjudul Manajement Control System menyatakan : 

"Manajement Control is the process by which managers influence other members of the organization to implement the organization's strategics".pengelolaannya memiliki kriteria sebagai berikut:

1. Pengendalian sistem administrasi dapat dipakai untuk mengontrol semua kegiatan, termasuk dalam pengelolaan terhadap semua kemampuan yang dapat digunakan, baik kemampuan daya manusia, teknologi dan perlengkapan pendukung ataupun hasil yang didapat dari kegiatan tersebut menjadi suatu jalan yang diharapkan akan berjalan dengan lancar sesuai tujuan.

2. Pengendalian sistem administrasi berlawanan dengan strategi dan cara evaluasi yang selaras secara menyeluruh, juga kurang mendetail secara terperinci ketika menganalisis sesuatu.

3. Pengendalian sistem administrasi lebih menyesuaikan terhadap manusia, karena pengendalian sistem administrasi lebih merujuk pada atasan guna mencapai suatu tujuan organization's strategics.

Suatu pengendalian sistem mempunyai bagian-bagian yang akan memungkinkan pengendalian tersebut berjalan dengan tepat. Bagian-bagian tersebut diantaranya adalah ( Halim dkk, 2009 :5 ) :

1. Sensor/detector, yaitu alat yang digunakan bertujuan untuk meneliti permasalahan apa yang akan terjadi di dalam suatu proses.

2. Asesor, yaitu alat yang digunakan untuk tujuan menentukan keakuratan. Biasanya menggunakannya cara membandingkan suatu kenyataan dengan standarisasi yang telah ditentukan.

3. Efektor, yaitu suatu alat yang dapat digunakan untuk merubah sesuatu yang didapat dari komponen asessor.

4. Jaringan komunikasi, yaitu alat yang dapat berguna untuk mentransfer informasi di antara detector assessor dan antara assessor dan efector.

Sistem pengendalian manajemen yang bisa diharapkan mesti bisa memiliki kriteria seperti dibawah ini (Sumarsan, 2011 : 9 ) :

1. Kemampuan pekerja harus sesuai terhadap tugas dan tanggung 

jawabnya.

2. Pembagian antar tugas.

3. Sistem pembagian tugas kerja, tujuannya adalah pengawasan yang cermat untuk pengeolaan atas segala pemasukan serta pengeluaran.

4. Pengendalian pengelolaan harta dan data-data yang di anggap penting.

5. Periksa kondisi pemasukan agar ketika di koreksi antara data di buku dan di lapangan tidak terjadi berbedaan .

Proses pengelolaan manajemen yang baik harus resmi, akan tetapi sikap pengelolaan yang tak resmi masih sering terjadi. Sehingga pengelolaan manajemen yang resmi merupakan tahapan yang saling berkaitan satu dengan lainnya, proses tersebut antara lain :

1. Pemrograman (Programming)

Pada tahapan ini perusahaan harus menentukan rencana yang akan dijalankan dan meneliti potensi yang akan dialokasikan untuk setiap rencana yang telah disepakati.

\section{Penganggaran (Budgeting)}

Pada bagian ini rencana penganggaran kinerja direncanakan secara terperinci,seperti yang diungkapkan dalam satu moneter, untuk suatu periode yang tentukan, normalnya adalah satu tahun.

3. Operasi dan Akuntansi (Operating and Accounting)

Pada bagian ini dilakukan pencatatan terhadap beberapa sumpotensi yang digunakan dan pendapatan yang didapat. rincian tersebut dikelompokan dengan rencana yang telah ditetapkan tanggungjawabnya. Pengelompokan yang sesuai rencana digunakan sebagai dasar untuk pemrogaman diwaktu yang akan mendatang, sedangkan pengelompokan yang sudah sesuai dengan pusat tanggungjawab akan digunakan untuk patokan kinerja para manajer di masa yang akan datang.

4. Laporan dan Analisis (Reporting and Analysis)

Pada bagian ini adalah hal yang paling penting karena 
Peran Sistem Pengendalian Manajemen Dalam Penerapan Strategi Relationship Marketing Azizah Konveksi di Desa Jatirunggo Kec. Pringapus untukmenutup suatu siklus dari proses pengendalian manajemen, supaya data yang didapat digunakan untuk proses pertanggungjawaban.

\subsubsection{Marketing (Pemasaran)}

Pemasaran adalah suatu pokok kegiatan perusahaan yang berinteraksi secara langsung terhadap konsumen. Tujuan utamanya adalah bekerja sama dengan pihak konsumen dengan cara mendapatkan beberapa keuntungan, atau lebih condong bersifat transaksional. Hal itu menunjukkan bahwa hubungan setelah penjualan harus diberi perhatian khusus dari pihak perusahaan. Dalam menjalin hubungan sama konsumen, perusahaan bisa menggunakan cara strategi relationship marketing. Strategi relationship marketing meliputi aktivitas seperti, menjalin kerjasama antara pelanggan dengan perusahaan. Relationship marketing dapat dilakukan dalam beberapa cara, meliputi :

1. Core service strategy yaitu membungkus layanan sebaik mungkin sehingga memenuhi keriteria pelanggan agar dapat memperkuat hubungan dengan konsumen,

2. Relasionship cuztomisazion yaitu melakukan penyesuaian layanan berdasarkan kebutuhan pelanggan juga pemanfaatan penggunaan teknologi informasi,

3. Service augmentation yaitu pengadaan layanan tambahan utama sehingga bisa membuat pemecahan dengan pesaing lain,

4. Relationship pricing, yaitu penggunaan insentif harga dalam upaya menarik pelanggan serta membangun hubungan dengan konsumen,

5. Internal marketing, yaitu membuat jaringan organisasi yang membuat para pekerja merasa aman menyampaikan kerjaan dengan cepat dan tepat

\section{METODE PENELITIAN}

\subsection{Jenis Penelitian}


Peran Sistem Pengendalian Manajemen Dalam Penerapan Strategi Relationship Marketing Azizah Konveksi di Desa Jatirunggo Kec. Pringapus Dari data pengelompokanya penelitian ini dikelompokan sebagai observasi yang deskriptif, karena hal ini cara pensajianya adalah dengan cara mengumpulkan data, mencari fakta aktual kemudian menjabarkan serta mengamati data yaitu caranya adalah mengamati, mengumpulkan dan menyusun data, kemudian diteliti kembali dan diterapkan berdasarkan apa yang menjadi landasan teori yang ada (Sugiyono, 2012:6).

\subsection{Waktu Dan Tempat Observasi}

Penelitian ini dilakukan di tahun ini yakni 2021 yaitu tepatnya diakhir bulan April. Salah satu objek pengamatan ini adalah Azizah Konveksi. Perusahaan ini adalah jasa yang bergerak di bidang tekstil, saudari Azizah sebagai pengelola AzizahKonveksi yang bertempat di Desa Jatirunggo Kec. Pringapus Kab. Semarang.

\subsection{Jenis-jenis dan Sumber Data}

\subsubsection{Data}

Data adalah catatan atas kumpulan fakta yang dipergunakan untuk menyusun hipotesa. Dalam hal ini data yang diperoleh adalah awal mula berdirinya Azizah Konveksi, lokasi Konveksi, fasilitas yang ada struktur organisasi perusahaan, jumlah karyawan, produk, daftar kegiatan, serta kinerja karyawan di Azizah Konveksi. Jadi, dari data yang digunakan dalam penelitian ini adalah termasuk data kualitatif yang merupakan penjabaran dalam bentuk kalimat yang baku.

\subsubsection{Jenis-jenis Data}

Berdasarkan dari jenisnya, data dibag jadi dua macam, yaitu :

1. Data Primer

Data primer adalah data yang didapat langsung dari narasumbernya, ditelaah dan dicatat secara langsung oleh pelakunya. Dalam hal ini data yang dikumpulkan adalah bagaimana penerapan strategi Relationship Marketing di Azizah Konveksi desa Jatirunggo Kec. Pringapus,yaitu berapa banyak pekerja, juga pengenmbangan juga cara mangajukanya. Hasil dari data tersebut dapat diperoleh secara langsung dengan cara mewawancarai bagian yang berwewenang dibagian ini, yaitu salah 

satunya adalah bagian dari HRD beserta jajaran pengelola Azizah Konveksi. Informasi yang di dapat berupa jawaban atas pertanyaan-pertanyaan yang ditanyakan melalui sesi interview langsung maupun tak langsung.

\section{Data Sekunder}

Data sekunder adalah data yang cara mendapatkanya bukan dari usaha sendiri oleh si peneliti. Dalam hal ini data yang dicerna adalah tentang bagaimana profil Azizah Konveksi di desa Jatirunggo Kec. Pringapus yaitu meliputi awal mula berdirinya konveksi ini , struktur organisasi dari perushaan, fasilitas yang ada serta daftar kegiatan ataupun program kerja.dari pengamatan ini data yang didapat adalah data dari informasi dari pihak ketiga misalnya : Koran, surat kabar, media internet dan lain-lain.

3. Sumber Data

Sumber data yang digunakan adalah melalui informan yakni pihak yang memberi berita tentang berbagai hal yang terlibat mengenai penelitian. Peneliti mendapat informasi dari saudari Azizah langsung sebagai pengelola dan pemilik perusahaan konveksi di desa Jatirunggo Kec. Pringapus. Kemudian dokumentasi, yakni mencari tau langsung dari hasil catatan perusahaan yang bisa dijadikan penelitian dengan cara mengolah informasi yang aktual.

\subsection{Teknik Pengumpulan Data}

Dalam penelitian ini peneliti menggunakan dua teknik dalam pengumpulan data, yakni :

\subsubsection{Pengamatan (Observasi)}

Peneliti melakukan pengumpulan data dengan cara pengamatan dan mencatat secara mendetail dari objek yang diteliti.. Dari hasil pengamatan (observasi) dapat diperoleh pandangan yang lebih jelas tentang masalahnya. Dengan cara penelitian, peneliti mendapatkan data tentang lokasi AzizahKonveksi , fasilitas yang dimiliki Azizah Konveksi dan proses strategi relationship marketing yang diterapkan Azizah Konveksi di desa Jatirunggo Kec. Pringapus. 


\subsubsection{Wawancara (Interview)}

Azizah Konveksi di Desa Jatirunggo Kec. Pringapus

Peneliti melakukan wawancara bertujuan untuk mengumpulkan data guna menemukan permasalahan yang akan diteliti dan untuk melengkapi data yang diperoleh dari hasil observasi. Dan dari hasil wawancara tersebut, para peneliti memperoleh informasi tentang sejarah berdirinya Azizah Konveksi di desa Jatirunggo Kec. pringapus dan gambaran strategi relationship marketing Azizah Konveksi.

\subsubsection{Dokumentasi}

Dengan mengenakan metode dokumentasi, peneliti memperoleh informasi tentang profil dari perusahaan Azizah Konveksi, struktur organisas perusahaan dan aktivitas perusahaan Azizah Konveksi di desa Jatirunggo Kec. Pringapus.

\subsection{Metode Analisa Data}

Analisa data adalah usaha yang dilakukan dengan cara menganalisis data, mengelompokan data, menyaring dari beberapa data dan dijadikan satukesatuan yang bisa dikelola,. Analisis data ini tujuanya adalah untuk mengetahui implementasi dari strategi Relationship Marketing di Azizah Konveksi Desa Jatirunggo Kec. Pringapus. Adapun cara analisa dari data yang digunakan dalam penelitian ini adalah analisa data kulitatif.

\section{HASIL PENELITIAN}

Bahwa hasil penelitian yang dihasilkan akan dilihat dari lima sudut pandang, yakni: analisa proses produksi, analisa produk rusak, analisa pengendalian proses produksi, analisa tenaga kerja, analisa mesin, dan analisa pemasaran.

\section{PEMBAHASAN}

\subsection{Analisa Proses Produksi}

Analisa proses produksi bermaksud untuk menganalisis bagaimana cara skema produksi yang dilakukan oleh perusahaan Konveksi. Dalam proses produksi ini perusahaan selalu mengamati dari proses produksinya, yaitu dangan cara mulai dari mengecek pola, bahan baku, dan juga desain yang akan di produksi. kemudian tidak lupa juga membuat urutan kerja, agar lebih mudah dalam proses produksi dan lebih efisien dalam pengerjaannya. 


\subsection{Analisa Produk Rusak.}

Setiap proses produksi, tidak semua barang atau pakaian yang di produksi itu baik pasti ada juga yang tidak sesuai dengan standar atau bisa dikatakan barang tersebut reject. Hal itu bias terjadi karena ada beberapa faktor :
a. Karyawan tidak cermat dalam bekerja,
b. Kondisi mesin yang bermasalah atau sudah tidak layak pakai,
c. Kurangnya ketelitian dalam pengecekan bahan-bahan,
d. Kurangnya ketelitian dalam pengecekan warna
e. Kurangnya ketelitian pada bagian Quality Control

\subsection{Analisa Pengendalian Proses Produksi}

Berdasarkan hasil pengamatan di lapangan, bahwasanya pengelolaan proses dari produksi yang dilakukan masih berjalan dengan maksimal, hal ini dikarenakan masih ditemukannya produk reject. Seperti pada pemasangan kancing, lepasnya benang obras di tengah jalan, noda pada kain yang sulit untuk di hilangkan. Sehingga membuat pihak konveksi harus memperbaiki kerusakan yang terjadi dan harius meminimalisir angka kerusakan,agar produk yang akan dihasilkan lebih meningkat kualitasnya.

\subsection{Analisa Tenaga Kerja}

Dari informasi yang didapat diatas, sering ditemukanya kerusakan yang sering terjadi adalah kurangnya ketelitian karyawan saat bekerja, sehingga hasil dari produk yang di hasilkan kualitasnya kurang maksimal. Dari kelalaian itu perlu adanya tindakan suatu pengawasan yang lebih khusus, guna memperkecil angka kerusakan yang terjadi, supaya dapat menghasilkan produk kualitas yang lebih baik. Konveksi tersebut sudah menerapkan pengendalian terhadap karyawan. Supaya mengurangi adanya tingkat kerusakan produk, akan tetapi tetap perlu diadakanya pengawasan kepada karyawan guna menghindari kesalahan yang sama.

\subsection{Analisa Mesin}

Dari informasi yang ada dilapangan, di akui bahwasanya mesin adalah bagian komponen yang sangat penting untuk melangsungkan pekerjaan dalam perusahaan konveksi, hal ini karena perlu didukung mesin yang baik untuk mendapatkan hasil produk yang baik juga. Perawatan mesin pada 
Peran Sistem Pengendalian Manajemen Dalam Penerapan Strategi Relationship Marketing Azizah Konveksi di Desa Jatirunggo Kec. Pringapus konveksi bisa dilakukan sebelum digunakan atau setelah digunakan sehingga dapat menghindari kerusakan yang akan terjadi.

\subsection{Analisa Pemasaran}

Berdasarkan data yang sudah terkumpul konsumen yang paling banyak adalah warga sekitar dan sudah sampai luar daerah. Biasanya pemesanan bisa mendatangi konveksi langsung atau juga bisa menghubungi pemilik secara langsung.Azizah konveksi ini melakukan penyebaran pamphlet melalui media sosial dan menempelkan pamphlet di tempat-tempat keramaian seperti pasar, toko-toko sekitar maupun tempat makan. Hal ini digunakan untuk meningkatkan pemesanan dan menambah order-an. Jadi, tidak hanya warga sekitar namun dari luar kota pun banyak yang bekerja sama dengan Azizah konveksi.Selain pengerjaanya yang cepat, hasilnya pun juga memuaskan pelanggan. Hal ini yang membuat para pelanggan selalu mempercayakan Azizah konveksi untuk bisnis bersama.

\section{KESIMPULAN}

Berdasarkan hasil penelitian oleh penulis maka menghasilkan kesimpulan sebagai berikut :

1. Berdasarkan analisa yang sudah dilakukan bahwa proses produksi pada Azizah Konveksi berjalan dengan lancar dan sangat baik

2. Berdasarkan analisa yang sudah dilakukan produk rusak bisa disebabkan oleh berbagai factor diantaranya yaitu mesin, kain, karyawan itu sendiri dan masih banyak lagi

3. Berdasarkan hasil dari pengamatan produksi pada Azizah Konveksi belum berjalan dengan maksimal, karena ada produk yang masih reject, dengan begitu pihak konveksi selalu memberikan kinerja yang optimal supaya mendapatkan kualitas produk yang maksimal

4. Berdasarkan hasil pengamatan Konveksi tersebut sudah menerapkan pengendalian terhadap karyawan supaya meminimalisir adanya kerusakan produk, akan tetapi tetap perlu adanya pengawasan kepada karyawan supaya tidak mengulangi kesalahan yang sama.

5. Berdasarkan hasil pengamatan perawatan mesin pada konveksi bisa 
Peran Sistem Pengendalian Manajemen Dalam Penerapan Strategi Relationship Marketing Azizah Konveksi di Desa Jatirunggo Kec. Pringapus dilakukan sebelum digunakan atau setelah digunakan sehingga dapat menghindari kerusakan yang akan terjadi.

6. Berdasarkan hasil pengamatan Azizah Konveksi sudah terkenal di kalangan warga sekitar karena prosesnya yang lebih cepat di bandingkan yang lain dan juga kualitasnya yang sangat bagus. Dengan begitu Azizah Konveksi kembali melakukan penyebaran pamphlet supaya bisa dikenal juga di daerah lain.

\section{REFERENSI}

Afita,S."Metode Penelitian”. (http://digilib.uinsby.ac.id/5250/7/Bab\%203.pdf) diakses pada 7 April 2021 jam 15.00 WIB.

Amdani, dan Trisnawati Nana. 2021. "Analisis Pengendalian Kualitas Produk Konveksi Dengan Menggunakan Metode Statistical Process Control pada CV. Fitria".Jurnal IKRA-ITH Ekonomika Vol. 4 No. 1.

Angelina, Pinda dan Santiko, Galih Cahyo. 2020. "Mini Riset Analisi Manajemen Pemasaran Adinda Konveksi Selama Pandemi Covied 19”. FE Universitas Tulungagung.

Budiartami, dan Wijaya I Wayan Kandi. 2019. “Analisi Pengendalian Proses Produksi Untuk Meningkatkan Kualitas Produk Pada CV.Cok Konfeksi Denpasar". Jurnal Manajemen dan Bisinis Equilibrium Vol. 5 No. 2, 161-166.

Imran. Dan Santi, Asih Putri. 2019. "Strategi Pemasaran Dalam Meningkatkan Penjualan pada CV. Raihan Konveksi dengan Pendekatan Blue Ocean Strategy".Jurnal Ekonomi 22 (2) (102-118).

Lekatompessy, Jantje Eduard. 2012. "Peran Sistem Pengendalian Manajemen Dalam Meningkatkan Kinerja Perusahaan : Analisis Kontinjensi dan Resource-Based View". Prodi Doktor Ilmu Ekonomi-UNDIP Semarang.

Muclish, Munawar. 2009. "Pengaruh Sistem Pengendalian Manajemen Terhadap Kinerja dalam Strategic Supply Relationship dengan Kerjasama Sebagai Variabel Intervening (peneliti empiris pada rumahsakit se-jawa)". TESIS. Progam Pascasarjana UNDIP-Semarang.

Musa, Sitti Hardianti. 2013. "Evaluasi Sistem Pengendalian Manajemen Untuk Meningkatkan Kinerja Manajer Penjualan Pada PT. Hasrat Abadi Manado". JURNAL EMBA. Vol.1 No. 4, Hal 1790-1798.

Sinain, Sifra Green. 2013. "Analisis Efektivitas Pengendalian Manajemen Penggajian PT. PLN (PERSERO) Rayon Tamohon”. JURNAL EMBA. Vol.1 No.3, Hal 1221-1230.

Sutanto, Ivana Afilia. 2018. "Evaluasi Sistem Pengendalian Manajemen Pada RestaurantK-Sushi" di Surabaya. Calyptra : Jurnal ilmiah Mahasiswa universitas Surabaya Vol. 7 No. 1.

Wirawan Agung. 2014. "Penerapan Strategi Relationship Marketing pada Hotel Sahid Montana Dua Malang". Skripsi. Program studi Manajemen, UPT Perpustakaan Universitas Malang. 